\title{
Thermal tolerance and potential distribution of Carvalhotingis visenda (Hemiptera: Tingidae), a biological control agent for cat's claw creeper, Macfadyena unguis-cati (Bignoniaceae)
}

\author{
K. Dhileepan*, D. Bayliss and M. Treviño \\ Queensland Department of Primary Industries \& Fisheries, Alan Fletcher \\ Research Station, Sherwood, Queensland 4075, Australia
}

\begin{abstract}
The specialist tingid, Carvalhotingis visenda, is a biological control agent for cat's claw creeper, Macfadyena unguis-cati (Bignoniaceae). Cat's claw creeper is an invasive liana with a wide climatic tolerance, and for biological control to be effective the tingid must survive and develop over a range of temperatures. We evaluated the effect of constant temperatures $\left(0-45^{\circ} \mathrm{C}\right)$ on the survival and development of $C$. visenda. Adults showed tolerance for wider temperature ranges $\left(0-45^{\circ} \mathrm{C}\right)$, but oviposition, egg hatching and nymphal development were all affected by both high $\left(>30^{\circ} \mathrm{C}\right)$ and low $\left(<20^{\circ} \mathrm{C}\right)$ temperatures. Temperatures between $20^{\circ} \mathrm{C}$ and $30^{\circ} \mathrm{C}$ are the most favourable for adult survival, oviposition, egg hatching and nymphal development. The ability of adults and nymphs to survive for a few days at high $\left(40^{\circ} \mathrm{C}\right.$ and $\left.45^{\circ} \mathrm{C}\right)$ and low $\left(0^{\circ} \mathrm{C}\right.$ and $\left.5^{\circ} \mathrm{C}\right)$ temperatures suggest that extreme temperature events, which usually occur for short durations (hours) in cat's claw creeper infested regions in Queensland and New South Wales states are not likely to affect the tingid population. The potential number of generations (egg to adult) the tingid can complete in a year in Australia ranged from three to eight, with more generations in Queensland than in New South Wales.
\end{abstract}

Keywords: thermal tolerance, potential distribution, weed, biological control, Australia

(Accepted 12 March 2009)

\section{Introduction}

Success of weed biological control agents is often determined by climatic factors which are critical to their establishment and effectiveness (e.g. Byrne et al., 2004). Of the various climatic factors, temperature plays a critical role in the survival and development of insects (e.g. Trudgill et al., 2005) and influences their geographic range and abundance

*Author for correspondence

Fax: 61-7-33796815

E-mail: k.dhileepan@dpi.qld.gov.au (e.g. Baars \& Heystek, 2003; Crozier, 2004; Diaz et al., 2008). A narrow temperature tolerance can diminish a biological control agent's ability to control a weed when it spans wide climatic variations in the introduced range (e.g. Dhileepan et al., 2005). Hence, information on the temperature tolerance of biological control agents is valuable to identify climatically suitable areas for field release (e.g. Simelane, 2007; Diaz et al., 2008), estimate population growth potential (e.g. McClay \& Hughes, 2007) and to understand why some agents have failed to establish in their introduced range (e.g. Coetzee et al., 2007).

Cat's claw creeper, Macfadyena unguis-cati (L.) Gentry (Bignoniaceae), has a wide geographic native range, from 


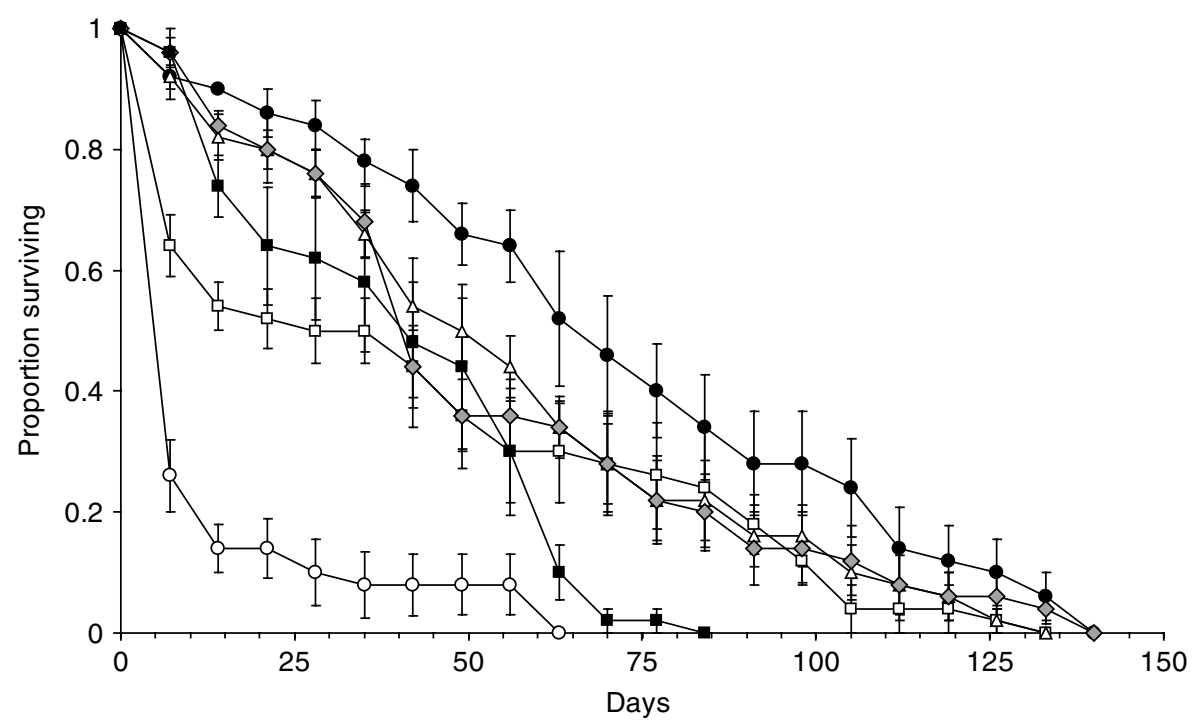

Fig. 1. Effect of constant temperatures on the survival of $\mathrm{C}$. visenda adults over time $\left(-\mathrm{O}_{-}, 10^{\circ} \mathrm{C} ;-\square-, 15^{\circ} \mathrm{C} ;-\mathbf{O}^{-}, 20^{\circ} \mathrm{C} ;-\triangle-, 25^{\circ} \mathrm{C}\right.$; $\left.\prec, 30^{\circ} \mathrm{C} ;-\square-, 35^{\circ} \mathrm{C}\right)$.

Mexico through Central America to tropical South America including Trinidad and Tobago (Everett, 1980; Howard, 1989). Cat's claw creeper also has a wide introduced geographic range across several countries, including Australia, South Africa, India, Mauritius, China, Hawaii and Florida in the USA and New Caledonia (Holm et al., 1991; Henderson, 1997; Meyer, 2000). Cat's claw creeper is a major environmental weed in its introduced ranges and is a target for classical biological control in Australia (Dhileepan et al., 2007a,b) and South Africa (Sparks, 1999; Williams et al., 2008). In both countries, cat's claw creeper occurs across varying climatic conditions (Rafter et al., 2008); and, for biological control to be effective, the agent must survive and develop in a range of temperature conditions.

The leaf-sucking tingid, Carvalhotingis visenda (Drake \& Hambleton) (Hemiptera: Tingidae), from Argentina and Brazil has been introduced as a biological control agent for cat's claw creeper in Australia (Treviño et al., 2006; Dhileepan et al., 2007a) and South Africa (Williams et al., 2008). Models using the 'Match Climate' function of CLIMEX for native (Brazil) and introduced (Australia) ranges suggests that $C$. visenda has the potential to cover most of the geographic range of cat's claw creeper in Australia (Rafter et al., 2008). However, a more rigorous climatic model using information on temperature tolerance of $C$. visenda would be valuable to identify suitable areas for field release. In this study, we evaluated the ability of $C$. visenda to survive and develop across a range of temperatures to understand its climatic tolerance and predict the potential number of generations the tingid could complete in a year in release sites in Australia.

\section{Materials and methods}

The study insect

The specialist cat's claw creeper leaf-sucking tingid, C. visenda, is native to Argentina, Brazil and Peru (Drake \&
Ruhoff, 1965; Montemayor \& Coscarón, 2005). A colony of C. visenda was established in South Africa from material collected on M. unguis-cati by Dr S. Neser from near Curitiba in Brazil and from Posadas in Argentina in April 2002. The tingid was identified by Dr Thomas J. Henry, from the Systematic Entomology Laboratory, USDA, Beltsville, Maryland, USA. The tingid, imported to Australia in 2004 as a potential biological control agent for cat's claw creeper (Treviño et al., 2006), was approved for field release in 2006 after detailed host specificity tests (Dhileepan et al., 2007a).

Females lay their eggs closely together in groups along the main vein on the undersides of cat's claw creeper leaves. The nymphs, which emerge after about 15 days, feed as a group, usually on the underside of leaves, by sucking out the cell contents of leaves and causing chlorosis. There are five nymphal instars and the total nymphal duration is about 15 days. Females start ovipositing eggs after eight days and produce up to 187 eggs in their lifetime (Williams et al., 2008). Adults are relatively long-lived; some adults have been found alive after two months (Dhileepan et al., 2007a; Williams et al., 2008).

\section{Experimental design}

Newly emerged $C$. visenda adults collected from a laboratory colony maintained in a glasshouse were used in the study. Potted cat's claw creeper plants of similar size were grown from field collected seedlings and used to sustain the tingids during the study. All tests were carried out in controlled temperature cabinets (Linder \& May Pty Ltd, Brisbane). The effect of temperature on adult survival, longevity, fecundity, incubation period, nymphal survival and nymphal development of $C$. visenda was studied at constant temperatures ranging from $0^{\circ} \mathrm{C}$ to $45^{\circ} \mathrm{C}$. An identical photoperiod (12 h light:12 h dark) was maintained in all cabinets. Humidity control was not possible, and therefore a tray of water was placed at the bottom of all cabinets to maintain the relative humidity at saturation level. 


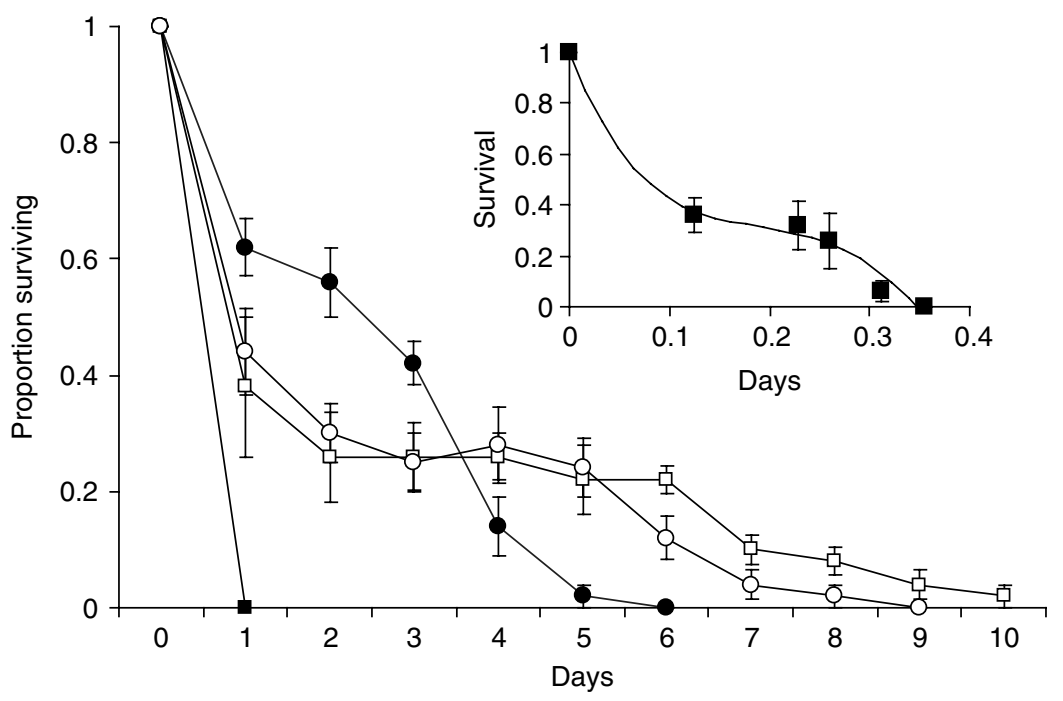

Fig. 2. Effect of constant high and low temperatures on the survival of $\mathrm{C}$. visenda adults over time $\left(-\mathbf{O}^{-}, 40^{\circ} \mathrm{C} ;-\square-, 45^{\circ} \mathrm{C} ;-\square-, 0^{\circ} \mathrm{C}\right.$; $\left.-\mathrm{O}-, 5^{\circ} \mathrm{C}\right)$.

In each cabinet were placed five potted cat's claw creeper plants, each with ten newly emerged adults (five males and five females), enclosed in a transparent plastic tube $(34 \mathrm{~cm}$ high and $12 \mathrm{~cm}$ diameter) with a gauze cap. Adult survival was monitored at least once every two days, with more frequent observations (every four hours) for higher $\left(40^{\circ} \mathrm{C}\right.$ and $\left.45^{\circ} \mathrm{C}\right)$ and lower $\left(0^{\circ} \mathrm{C}\right.$ and $\left.5^{\circ} \mathrm{C}\right)$ temperatures. Oviposition, if any, was recorded at weekly intervals, and the number of eggs oviposited on each plant counted from the second week onwards until all adults died. The first batch of eggs in each potted plant was retained in the same temperature cabinet and monitored for hatching and nymphal development. In temperatures where either oviposition or egg hatching did not occur $\left(\leq 15^{\circ} \mathrm{C}\right.$ and $\left.\geq 35^{\circ} \mathrm{C}\right)$, cat's claw creeper with newly emerged nymphs $(<12 \mathrm{~h}$ old) from the $25^{\circ} \mathrm{C}$ cabinet were transferred to these respective temperatures and their survival and development monitored daily with more frequent observations (every four hours) for higher $\left(\geq 40^{\circ} \mathrm{C}\right)$ and lower $\left(\leq 5^{\circ} \mathrm{C}\right)$ temperatures.

\section{Data analysis}

The duration of adult survival (longevity) and the number of eggs/female were calculated for each potted plant within a temperature cabinet and these means were used in subsequent analyses. One-way ANOVA was used with temperature as the fixed factor and adult longevity (days), number of eggs/female, proportion of eggs hatched and proportion of nymphs developed into adults, as the response variables. Data were log-transformed prior to the analysis to homogenize variance and normalize the residuals. Survival over time was explored by regressing proportion (mean of five replications) surviving over time at each temperature. All results in the text are presented as means \pm standard error.

For egg and nymph, based on the developmental time at each temperature, linear regression $(y=a+b t)$ was fitted to the developmental rates $(y)$ versus temperatures $(t)$, where $a$ and $b$ were estimates of the $y$ intercept and slope,

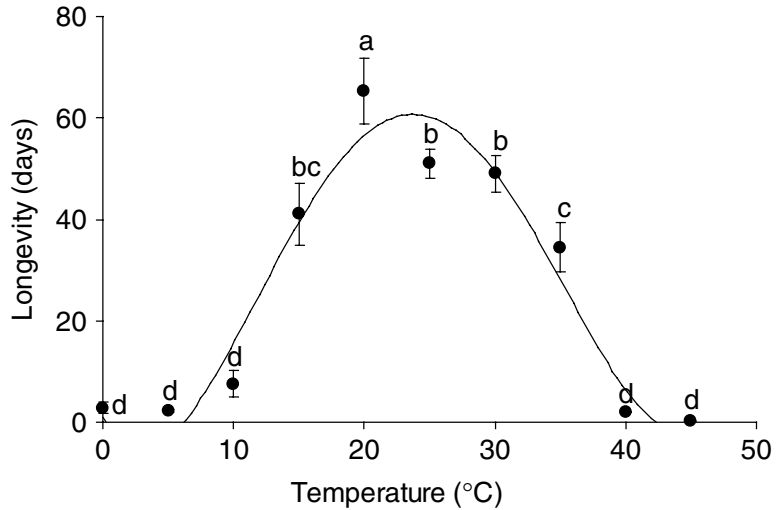

Fig. 3. Effect of constant temperatures on the longevity (mean\pm SEM) of $C$. visenda adults $\left(y=0.0004 x^{4}-0.0342 x^{3}+0.905 x^{2}-\right.$ $\left.4.531 x+1 ; R^{2}=0.944\right)$. Fisher LSD, means with same alphabets are not significantly different (alpha $=0.05$ ).

respectively. Degree-day (DD) requirement for egg and nymph was estimated by the reciprocal of the slope $(b)$ of the fitted linear regression $(\mathrm{DD}=1 / b)$ (i.e. Diaz et al., 2008). The mean ( $>20$ years) DD accumulated for each month over the lower developmental threshold $\left(t_{\mathrm{b}}\right)$ was calculated from monthly mean of maximum $\left(t_{\max }\right)$ and minimum $\left(t_{\min }\right)$ temperatures $\left(\left[t_{\max }+t_{\min } / 2\right]-t_{\mathrm{b}}\right)$ obtained from the online climate database (www.bom.gov.au/climate/averages). The mean annual DD accumulated over the lower developmental threshold was calculated for 16 sites in Queensland and eight sites in New South Wales (NSW) with or near cat's claw creeper infestation. The potential number of generations the tingid could complete in a year at each site was predicted by dividing the cumulative DD accumulated over the lower developmental threshold in a location by the DD requirement of the tingid to complete development (e.g. Larentzaki et al., 2007). A map of the potential number of 


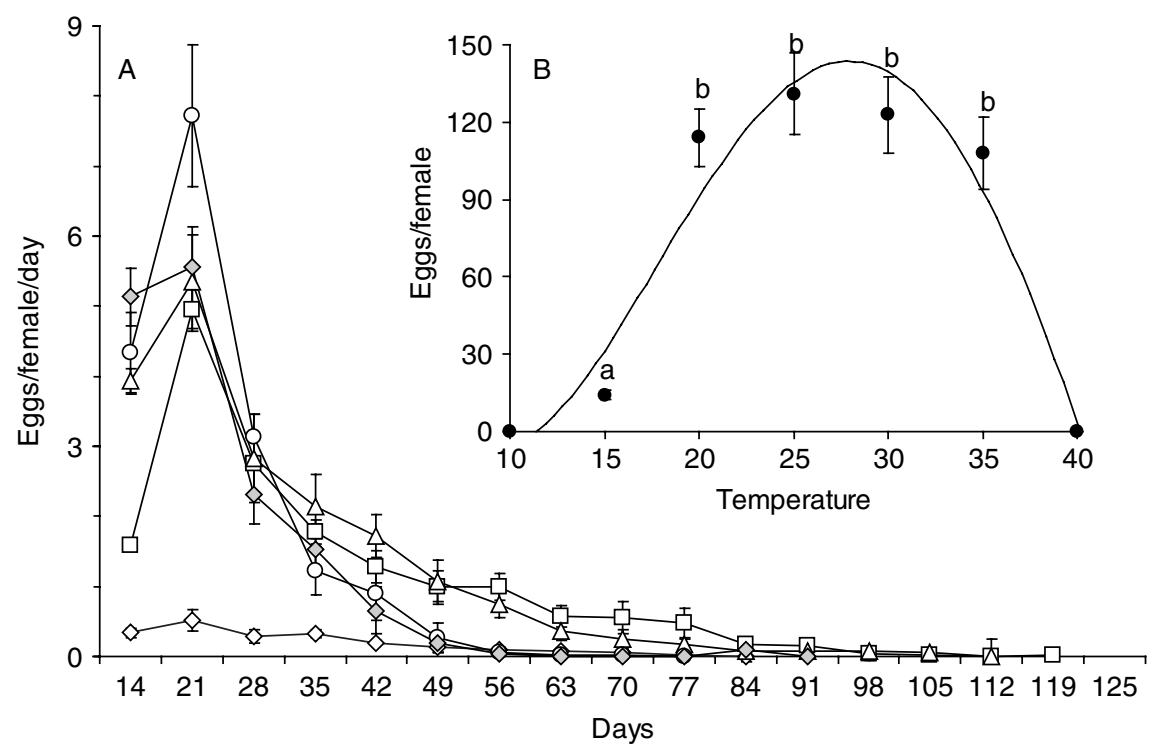

Fig. 4. Effect of constant temperature on (A) the number of eggs per female per day (mean \pm SEM) and (B) the number of eggs per female $($ mean \pm SEM $)\left(y=-0.588 x^{2}+30.81 x-273.83 ; R^{2}=0.856\right)$ in $C$. visenda. Fisher LSD, means with same alphabets are not significantly different (alpha $=0.05)\left(-\diamond-15^{\circ} \mathrm{C} ;-\square-, 20^{\circ} \mathrm{C} ;-\triangle-, 25^{\circ} \mathrm{C} ;-\mathrm{O}^{-}, 30^{\circ} \mathrm{C} ; \smile-35^{\circ} \mathrm{C}\right)$.

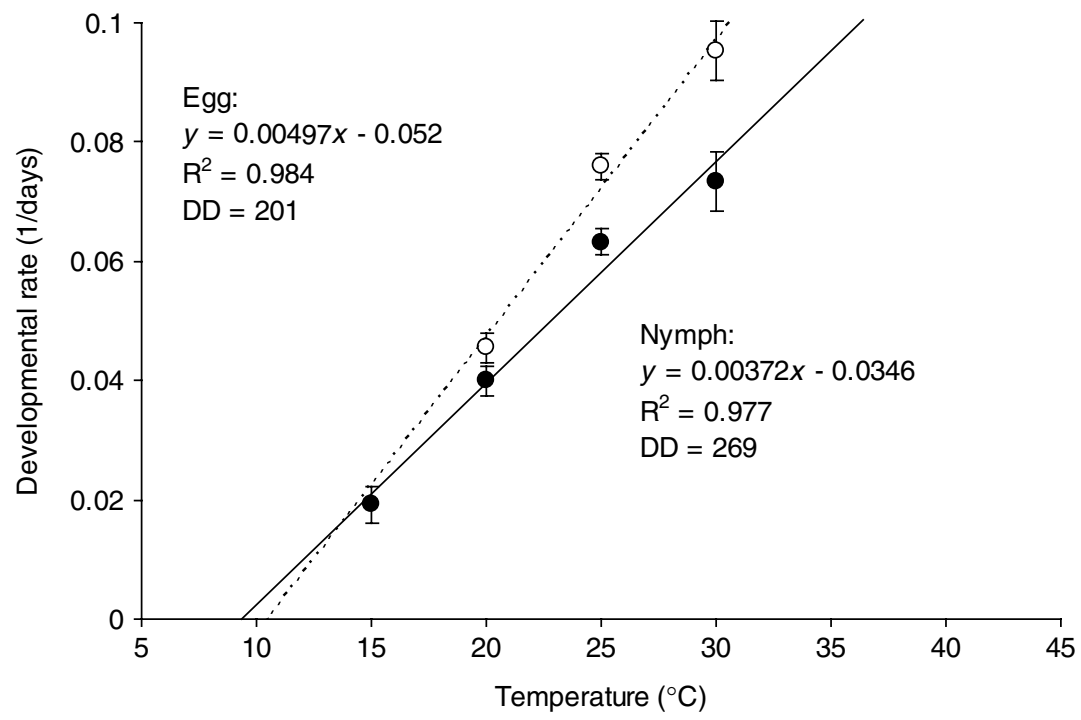

Fig. 5. Effect of constant temperature on the developmental rate (day $\left.{ }^{-1}\right)($ mean \pm SEM) of C. visenda eggs and nymphs $(\bullet$, nymph; , egg).

generations the tingid could complete each year at sites with or near cat's claw creeper infestation was generated using the ArcGIS 9 program.

\section{Results}

\section{Adult survival and longevity}

Adult survival declined over time and the decline was more rapid at low $\left(0^{\circ} \mathrm{C}\right.$ and $\left.5^{\circ} \mathrm{C}\right)$ and high $\left(40^{\circ} \mathrm{C}\right.$ and $\left.45^{\circ} \mathrm{C}\right)$ temperatures (figs 1 and 2). Temperature significantly influenced adult longevity (One-way ANOVA, $\mathrm{F}_{9,40}=47.7$, $P<0.001)$, which increased with the increase in temperature from $10^{\circ} \mathrm{C}$ to $20^{\circ} \mathrm{C}$, but declined after that (fig. 3). Adults survived up to four months in temperatures between $15^{\circ} \mathrm{C}$ and $30^{\circ} \mathrm{C}$ (fig. 1), and the maximum longevity was obtained at $20^{\circ} \mathrm{C}$ (fig. 3). At $40^{\circ} \mathrm{C}$ and $45^{\circ} \mathrm{C}, 50 \%$ of adults survived for three days and two hours, respectively, and at $0^{\circ} \mathrm{C}$ and $5^{\circ} \mathrm{C}$, $50 \%$ of adults survived less than a day (fig. 2). As a result, adult longevity remained very low at high $\left(40^{\circ} \mathrm{C}=2.0 \pm 0.05\right.$ days; $45^{\circ} \mathrm{C}=0.2 \pm 0.01$ days $)$ and low $\left(0^{\circ} \mathrm{C}=2.8 \pm 1.07\right.$ days; $5^{\circ} \mathrm{C}=2.2 \pm 0.28$ days) temperatures (fig. 3 ). 


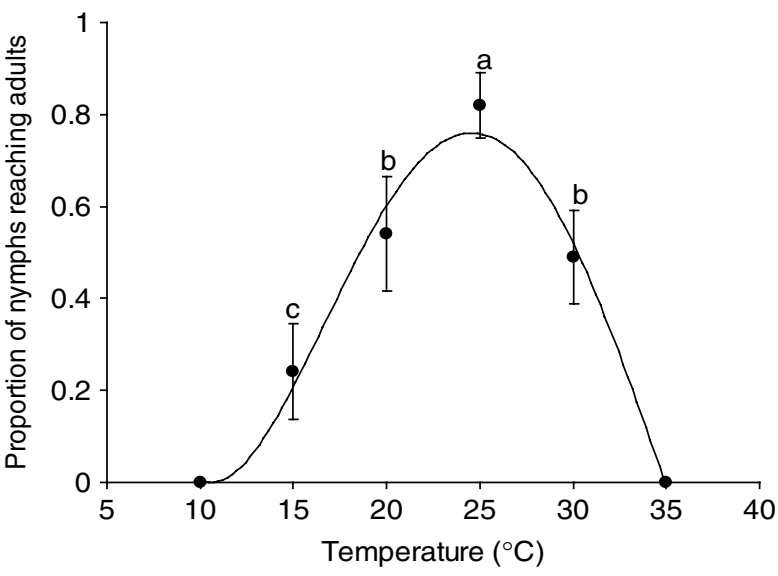

Fig. 6. Effect of constant temperature on the proportion of C. visenda nymphs (mean \pm SEM) becoming adults $\left(y=0.002 x^{3}+\right.$ $0.061 x^{2}-0.762 x+3.19 ; R^{2}=0.982$ ). Fisher LSD, means with same alphabets are not significantly different (alpha $=0.05)$.

\section{Oviposition and incubation period}

Oviposition was evident only between $15^{\circ} \mathrm{C}$ and $35^{\circ} \mathrm{C}$; and, at all these temperatures, the average number of eggs per female per day declined over time (fig. 4a). At $20^{\circ} \mathrm{C}$ and $25^{\circ} \mathrm{C}$, females continued to lay eggs for up to 12 weeks (fig. 4a). Temperature had a significant impact on the number of eggs per female (One-way ANOVA, $F_{4,20}=14.57$, $P<0.001)$. The number of eggs per female did not differ significantly at temperatures between $20^{\circ} \mathrm{C}$ and $35^{\circ} \mathrm{C}$ but was significantly higher than at $15^{\circ} \mathrm{C}$ (fig. $4 \mathrm{~b}$ ).

Egg hatching occurred only between $20^{\circ} \mathrm{C}$ and $30^{\circ} \mathrm{C}$, and there was no difference in the proportion of eggs hatched within that temperature range. None of the eggs laid at $\leq 15^{\circ} \mathrm{C}$ and $\geq 35^{\circ} \mathrm{C}$ hatched. However, exposure of less than day-old eggs of up to six hours at $35^{\circ} \mathrm{C}$ and $40^{\circ} \mathrm{C}$ had no negative impact on egg hatching. The rate of egg development increased with increasing temperature and maximum egg development occurred at $30^{\circ} \mathrm{C}$ (fig. 5). The DD required for egg development was 201 (fig. 5).

\section{Nymphal survival and development}

Nymphs developed into adults only between $15^{\circ} \mathrm{C}$ and $30^{\circ} \mathrm{C}$ (fig. 6), but the proportion of nymphs that developed into adults differed significantly between temperatures (oneway ANOVA, $\left.F_{4,20}=16.41,<0.001\right)$. The highest proportion of nymphs became adults at $25^{\circ} \mathrm{C}$ (fig. 6). At $35^{\circ} \mathrm{C}$ and $40^{\circ} \mathrm{C}$, $50 \%$ of nymphs survived for five days and 12 hours, respectively (fig. 7), but none of these developed into adults. As a result, the duration of nymphal survival remained low at temperatures above $30^{\circ} \mathrm{C}\left(35^{\circ} \mathrm{C}=3.6 \pm 0.58\right.$ days; $40^{\circ} \mathrm{C}=$ $15.5 \pm 4.4$ hours). At $10^{\circ} \mathrm{C}$ nymphs survived for $16.7 \pm 0.39$ days, but none of them developed into adults. The rate of nymphal development increased with the increasing temperature from $15^{\circ} \mathrm{C}$ to $30^{\circ} \mathrm{C}$ (fig. 5) and the DD required for nymphal development was 269 (fig. 5). The potential number of generations (egg to adult) the tingid can complete in a year ranged from three to eight, with more generations in Queensland than in the NSW (fig. 8).

\section{Discussion}

The study, though mainly concentrating on the effect of temperature, represents the combined effect of temperature and high humidity. The results suggest that eggs and nymphs have a narrower range of temperature tolerance than do adults. Eggs and immature stages are known to be more susceptible than adults in other insects also (e.g. Lale \& Vidal, 2000). Temperatures between $20^{\circ} \mathrm{C}$ and $30^{\circ} \mathrm{C}$ are the most favourable for adult survival, oviposition and nymphal development, while egg hatching occurred only between $20^{\circ} \mathrm{C}$ and $30^{\circ} \mathrm{C}$. Though fecundity was low at $15^{\circ} \mathrm{C}$, it was

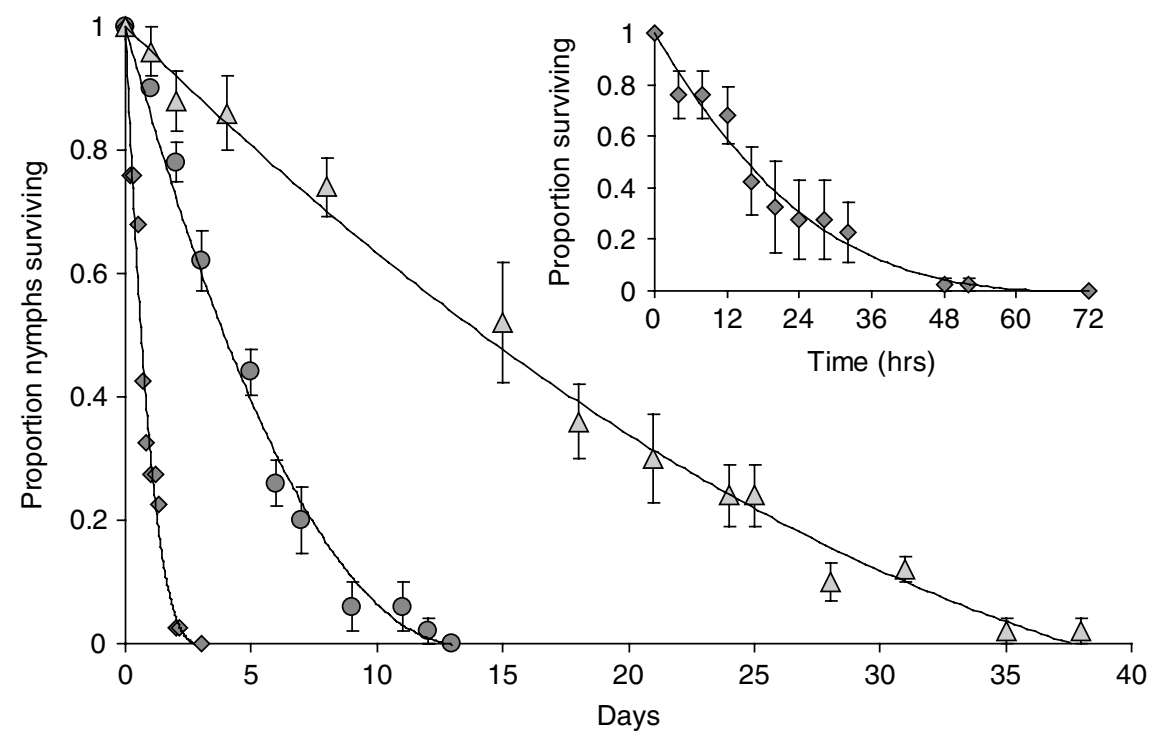

Fig. 7. Effect of constant high $\left(40^{\circ} \mathrm{C}\right.$ and $\left.45^{\circ} \mathrm{C}\right)$ and low $\left(10^{\circ} \mathrm{C}\right)$ temperatures on the survival (mean \pm SEM) of $\mathrm{C}$. visenda nymphs over time $\left(0,35^{\circ} \mathrm{C} ; \diamond, 40^{\circ} \mathrm{C} ; \triangle, 10^{\circ} \mathrm{C}\right)$. 


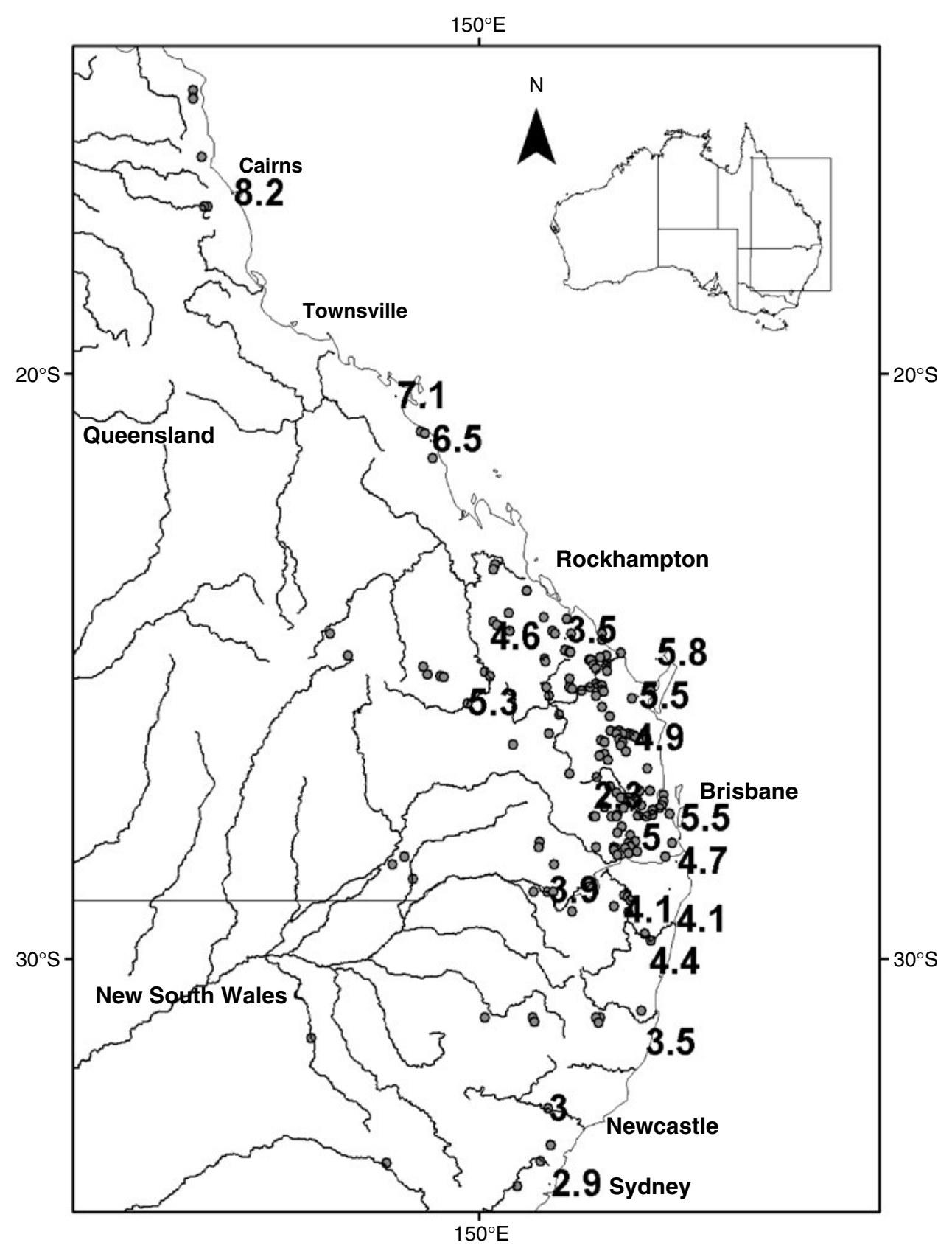

Fig. 8. Potential number of generations that C. visenda can complete in a year in cat's claw creeper infested areas in Queensland and NSW, Australia (O, cat's claw creeper; -, rivers).

not affected by temperatures between 20 and $35^{\circ} \mathrm{C}$, as reported in other tingids (Cividanes et al., 2004). Though the rates of decline in adult and nymphal survival were higher at low $\left(0^{\circ} \mathrm{C}\right.$ and $\left.5^{\circ} \mathrm{C}\right)$ and high $\left(40^{\circ} \mathrm{C}\right.$ and $\left.45^{\circ} \mathrm{C}\right)$ temperatures, both adults and nymphs survived for a few days at high and low temperatures (figs 2 and 7). Hence, it is unlikely that either higher or lower temperatures will drastically affect the tingid population, as most areas where cat's claw creeper is targeted for biological control are riparian areas, and are known to experience only limited durations (maximum of a few hours a day) of low $\left(\leq 5^{\circ} \mathrm{C}\right)$ or high $\left(\geq 40^{\circ} \mathrm{C}\right)$ temperatures.

Although adults showed tolerance for wide temperature ranges $\left(0-45^{\circ} \mathrm{C}\right)$, oviposition, egg hatching and nymphal development are all affected by both high $\left(>30^{\circ} \mathrm{C}\right)$ and low $\left(<20^{\circ} \mathrm{C}\right)$ temperatures. Nymphs were shown to be more susceptible to low and high temperatures than adults. Prolonged nymphal survival at lower temperatures is attributed to the species' ability to form dense aggregations, a behaviour reported in other insects also (i.e. Braman \& 
Pendley, 1993; Bryant et al., 2000; Danks, 2002). At high temperatures, the nymphs exhibited thermal avoidance behaviour, by moving into the soil to avoid exposure to warm conditions, a behaviour also known in other insects (i.e. Gang \& Chunsen, 2007). Adults survived significantly longer than nymphs at lower temperatures, but neither adults nor nymphs exhibited any overwintering or diapause behaviour. As a result, both nymphs and adults remain active throughout the year, including the winter months in the field.

The relative humidity, though not studied here, could also affect the survival and development of the tingid. In Australia, cat's claw creeper occurs mainly in riparian areas (fig. 8; Rafter et al., 2008), where the microclimate provides protection from frost, and the increased soil moisture would enable species to exist in areas where the macroclimate is unfavourable (Kriticos et al., 2003). Although the inland areas, based on macroclimates, may appear unfavourable for the tingid due to prolonged dry and cold conditions, the riparian microclimates may remain favourable for the tingid. A previous climate-matching model also suggested that the majority of the areas with cat's claw creeper infestation in Australia are suitable for the tingid (Rafter et al., 2008). The DD requirements of $C$. visenda suggest that the potential number of generations (egg to adult) the tingid can complete in a year in the cat's claw creeper infested areas in Australia ranged from three to eight (fig. 8). Similar multiple generations in a year by other tingids in the tropics have been reported (e.g. Romero et al., 2000; Cividanes et al., 2004). Though it appears that $C$. visenda could complete equal numbers of generations in the inland regions as in the coastal areas (fig. 8), dry stress in inland regions may restrict the suitability of these areas for the tingid. The predictions from this study and from the earlier climate-matching model (Rafter et al., 2008) are currently being field tested by releasing the tingid and monitoring its establishment in both inland and coastal areas of Queensland and NSW.

\section{Acknowledgements}

We thank Stefan Nesar and Hester Williams (PPRI, South Africa) for supplying tingid, Jayd McCarthy and Mathew Shortus for technical support and Wilmot Senaratne and Fernando Chandima for the ArcGIS map. Comments from Bill Palmer and Dane Panetta helped improve this manuscript.

\section{References}

Baars, J.R. \& Heystek, F. (2003) Geographical range and impact of five biocontrol agents established on Lantana camara in South Africa. BioControl 48, 743-759.

Braman, S.K. \& Pendley, A.F. (1993) Temperature, photoperiod and aggregation effects on development, diapause, reproduction and survival of Corythucha cydoniae (Heteroptera: Tingidae). Journal of Entomological Science 28, 417-426.

Bryant, S.R., Thomas, C.D. \& Bale, J.S. (2000) Thermal ecology of gregarious and solitary nettle-feeding nymphalid butterfly larvae. Oecologica 122, 1-10.

Byrne, M.J., Coetzee, J., McConnachie, A.J., Parasram, W. \& Hill, M.P. (2004) Predicting climate compatibility of biological control agents in their region of introduction. pp. 28-34 in Cullen, H.M., Briese, D.T., Kriticos, D.J.,
Lonsdale, W.M., Morin, L. \& Scott, J.J. (Eds) Proceedings of the XI International Symposium on Biological Control of Weeds. CSIRO Entomology, 27 April-2 May 2003, Canberra, Australia.

Cividanes, F.J., Julio, F.S. \& Galli, J.C. (2004) Biology of Leptopharsa heveae Drake \& Poor (Heteroptera: Tingidae) and the relationship of its thermal requirements with population fluctuation in rubber tree. Neotropical Entomology 33, 685691.

Coetzee, J.A., Byrne, M.J. \& Hill, M.P. (2007) Predicting the distribution of Eccritotarsus catarinensis, a natural enemy released on water hyacinth in South Africa. Entomologia Experimentalis et Applicata 125, 237-247.

Crozier, L.G. (2004). Field transplants reveal summer constraints on a butterfly range expansion. Oecologica 141, 148-157.

Danks, H.V. (2002) Modifications of adverse conditions by insects. Oikos 99, 10-24.

Dhileepan, K., Trevino, M. \& Raghu, S. (2005) Effect of temperature on the survival of Aconophora compressa (Hemiptera: Membracidae): Implications for weed biocontrol. Australian Journal of Entomology 44, 457-462.

Dhileepan, K., Treviño, M. \& Snow, E.L. (2007a) Specificity of Carvalhotingis visenda (Hemiptera: Tingidae) as a biological control agent for cat's claw creeper Macfadyena unguis-cati (Bignoniaceae) in Australia. Biological Control 41, 282-290.

Dhileepan, K., Snow, E.L., Rafter, M.A., Treviño, M., McCarthy, J. \& Wilmot Senaratne, K.A.D. (2007b) The leaf-tying moth Hypocosmia pyrochroma (Lepidoptera: Pyralidae), a host specific biological control agent for cat's claw creeper Macfadyena unguis-cati (Bignoniaceae) in Australia. Journal of Applied Entomology 131, 564-568.

Diaz, R., Overhold, W.A., Samayoa, A., Sosa, F., Cordeau, D. \& Medal, J. (2008) Temperature-dependent development, cold tolerance and potential distribution of Gratiana boliviana (Coleoptera: Chrysomelidae), a biological control agent of tropical soda apple, Solanum viarum (Solanaceae). Biocontrol Science and Technology 18, 193-207.

Drake, C.J. \& Ruhoff, F.A. (1965) Lacebugs of the world: A catalog (Hemiptera: Tingidae). Bulletin 243, Smithsonian Institution, United States National Museum, pp. 634, Washington, DC, USA.

Everett, T.H. (1980) The New York Botanical Garden illustrated Encyclopaedia of Horticulture. Vol. 6. 2130 pp. New York \& London, Garland Publishing Inc.

Gang, M. \& Chunsen, M. (2007) Behavioural responses of bird cherry-oat aphid, Rhopalosiphum padi, to temperature gradients (abstract). Acta Phytophylacica Sinica 34, 624630.

Henderson, R.J.F. (1997) Queensland Plants: Names and Distribution. 284 pp. Brisbane, Australia, Queensland Herbarium.

Holm, L.G., Pancho, J.V., Herberger, J.P. \& Plucknett, D.L. (1991) A Geographical Atlas of World Weeds. 391 pp. Malabar, Florida, USA, Krieger Publishing Company.

Howard, R.A. (1989) Flora of the Lesser Antilles: Leeward and Windward Islands. Dicotyledoneae. Vol. 6. 658 pp. Jamaica Plain, MA, USA, Arnold Arboretum, Harvard University.

Kriticos, D.J., Sutherst, R.W., Brown, J.R., Adkins, S.W. \& Maywald, G.F. (2003) Climate change and biotic invasions: A case history of a tropical woody vine. Biological Invasions 5, 147-165.

Lale, N.E.S. \& Vidal, S. (2000) Mortality of different developmental stages of Callosobruchus maculatus F. and Callosobruchus subinnotatus Pic. (Coleoptera: Bruchidae) in bambara groundnut Vigna subterranea (L.) Verdc. seeds 
exposed to simulated solar heat. Zeitschrift für Pflanzenkrankheiten und Pflanzenschutz 107, 553-559.

Larentzaki, E., Powell, G. \& Copland, M.J.W. (2007) Effect of temperature on development, overwintering and establishment potential of Franklinothrips vespiformis in the UK. Entomologia Experimentalis et Applicata 124, 143-151.

McClay, A.S. \& Hughes, R.B. (2007) Temperature and hostplant effects on development and population growth of Mecinus janthinus (Coleoptera: Curculionidae), a biological control agent for invasive Linaria spp. Biological Control 40, 405-410.

Meyer, J.Y. (2000) Preliminary review of the invasive plants in the Pacific islands (SPREP Member countries). pp. 85-114 in Sherley, G. (Ed.) Invasive Species in the Pacific: A Technical Review and Draft Regional Strategy. Samoa, South Pacific Regional Environment Programme.

Montemayor, S. \& Coscarón, M.D.C. (2005) List of Argentinean Tingidae Laporte (Heteroptera) with their host plants. Zootaxa 1065, 29-50.

Rafter, M.A., Wilson, A.J., Wilmot Senaratne, K.A.D. \& Dhileepan, K. (2008) Climatic-requirements models of cat's claw creeper Macfadyena unguis-cati (Bignoniaceae) to prioritise areas for exploration and release of biological control agents. Biological Control 44, 169-179.

Romero, M.L., Ravelo, G.H. \& Rodriguez, H.V. (2000) Biologia de Pseudacysta perseae (Heid.) (Heteroptera: Tingidae) a temperatura constante (Spanish). Centro Agricola 27, 39-41.

Simelane, D.O. (2007) Influence of temperature, photoperiod and humidity on oviposition and egg hatch of the rootfeeding flea beetle Longitargus bethae (Chrysomelidae: Alticinae), a natural enemy of the weed Lantana camara (Verbenaceae). Bulletin of Entomological Research 97, 111-116.

Sparks, H.E. (1999) The initiation of a biological control programme against Macfadyena unguis-cati (L.) Gentry (Bignoniaceae) in South Africa. African Entomology Memoir No. 1, 153-157.

Treviño, M., Snow, E.L., Seneratne, W., Conrad, C. \& Dhileepan, K. (2006) Leaf-sucking tingid (Carvalhotingis visenda): A potential biological control agent for cat's claw creeper (Macfadyena unguis-cati). pp. 605-606 in Preston, C., Watts, J.H. and Crossman, N.D. (Eds) Proceedings of the Fifteenth Australian Weeds Conference. Weed Management Society of South Australia, Adelaide, SA, Australia.

Trudgill, D.L., Honek, A., Li, D. \& Van Straalen, N.M. (2005) Thermal time - concepts and utility. Annals of Applied Biology 146, 1-14.

Williams, H., Neser, S. \& Madire, L.G. (2008) Candidates for biocontrol of Macfadyena unguis-cati in South Africa: Biology, host-ranges and potential impact of Carvalhotingis visenda and Carvalhotingis hollandi under quarantine conditions. BioControl 53, 945-956. 